Article

\title{
Resting Metabolic Rate in Women with Endocrine and Osteoporotic Disorders in Relation to Nutritional Status, Diet and 25(OH)D Concentration
}

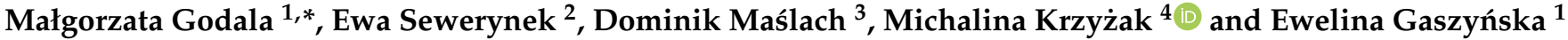 \\ 1 Department of Nutrition and Epidemiology, Medical University of Lodz, No.7/9 Żeligowskiego St., \\ 90-752 Łódź, Poland; ewelina.gaszynska@umed.lodz.pl \\ 2 Department of Endocrine Disorders and Bone Metabolism, Medical University of Lodz, \\ No.7/9 Żeligowskiego St., 90-752 Łódź, Poland; ewa.sewerynek@umed.lodz.pl \\ 3 Department of Public Health, Medical University of Bialystok, No.37 Szpitalna St., 15-295 Bialystok, Poland; \\ dominikm@umb.edu.pl \\ 4 Department of Hygiene, Epidemiology and Ergonomics, Medical University of Bialystok, No.2c Mickiewicza St., \\ 15-022 Bialystok, Poland; michalina.krzyzak@umb.edu.pl \\ * Correspondence: malgorzata.godala@umed.lodz.pl
}

check for

updates

Citation: Godala, M.; Sewerynek, E.; Maślach, D.; Krzyżak, M.;

Gaszyńska, E. Resting Metabolic Rate in Women with Endocrine and Osteoporotic Disorders in Relation to Nutritional Status, Diet and 25(OH)D Concentration. Int. J. Environ. Res. Public Health 2022, 19, 3118. https:// doi.org/10.3390/ijerph19053118

Academic Editors: Eusebio Chiefari and Peter Ebeling

Received: 20 December 2021

Accepted: 15 February 2022

Published: 7 March 2022

Publisher's Note: MDPI stays neutral with regard to jurisdictional claims in published maps and institutional affiliations.

Copyright: (C) 2022 by the authors. Licensee MDPI, Basel, Switzerland. This article is an open access article distributed under the terms and conditions of the Creative Commons Attribution (CC BY) license (https:/ / creativecommons.org/licenses/by/ $4.0 /)$.

\begin{abstract}
There are speculations that vitamin $\mathrm{D}$ may be an important regulator of the energy metabolism. The aim of this study was to evaluate the influence of serum $25(\mathrm{OH}) \mathrm{D}$ concentration and nutritional status on the resting metabolic rate. The study group consisted of 223 women with endocrine and/or osteoporotic disorders. The control group consisted of 108 women, clinically healthy. The total $25(\mathrm{OH}) \mathrm{D}$ concentration level was measured with an assay using chemiluminescent immunoassay technology. Indirect calorimetry was applied to assess the resting metabolic rate. The mean resting metabolic rate was significantly lower in the group of women with metabolic disorders than in the control group. A correlation was found between serum $25(\mathrm{OH}) \mathrm{D}$ levels in healthy subjects and the resting metabolic rate. Significantly higher resting metabolic rate was found in women with normal serum $25(\mathrm{OH}) \mathrm{D}$ levels in comparison to subjects with deficient vitamin $\mathrm{D}$ levels. The control group demonstrated a relationship between body fat tissue and fat-free body mass and the resting metabolic rate. Both $25(\mathrm{OH}) \mathrm{D}$ concentration and body composition were factors influencing the resting metabolic rate in the group of healthy subjects. More research is needed to clarify the relationship between vitamin D status and metabolic rate in individuals with endocrine and osteoporotic disorders.
\end{abstract}

Keywords: resting metabolic rate; $25(\mathrm{OH}) \mathrm{D}$; diet; metabolic disorders; osteoporotic disorders

\section{Introduction}

The resting metabolic rate, also called resting energy expenditure, is one of components of the total energy demand and it makes up its greater portion. Apart from basic factors that undoubtedly influence the value of the demand, such as fat body mass and fat-free body mass, gender, age, or ethnicity, the variability of resting metabolism in different groups of patients makes it necessary to search for other factors predicting its value. Energy homeostasis is vital for normal functioning of the body. However, in the event of metabolic changes, depleting adaptive mechanisms disturb its balance. In a study, a group of patients with metabolic diseases demonstrated lower values of the basal metabolic rate, which might indicate that there are factors which lower the rate of energy metabolism in these patients and which are not normally taken into account in the assessment of the resting metabolic rate, such as vitamin and mineral deficiencies or hormone imbalances [1-3]. A perusal of the resting metabolic rate literature reveals that considerable information on studies of specific population subgroups, e.g., patients with metabolic disorders, are sparse, especially as far as non-specific factors influencing resting metabolic rate are concerned. 
Maintenance of the body energy balance is primarily related to dietary energy supply. However, selected nutrients also contribute to the maintenance of this balance by accelerating or slowing down the metabolic rate. Food intake itself induces energy expenditure related to the so-called thermic effect of food, but there are hypotheses denying the effectiveness of this process in individuals with metabolic disorders [4-6]. Nutrients, including proteins, fats, carbohydrates, and dietary fibre, are believed to affect energy expenditure despite there being no conclusive evidence for their effect. In addition to basal metabolism, physical activity is an important component of 24-h energy expenditure. Many studies on a possible influence of physical activity on the resting metabolic rate are contradictory. However, a few authors suggest that the modulating effect of physical activity on the energy metabolism rate occurs when it is accompanied by a decrease in body weight $[7,8]$.

In recent years, vitamin $\mathrm{D}$ deficiency, which has long been regarded as a risk factor for many diseases and not only a regulator of calcium-phosphate metabolism, has been widely discussed. Results of many studies have confirmed the very frequent occurrence of serum $25(\mathrm{OH}) \mathrm{D}$ deficiency in patients with metabolic syndrome, cardiovascular disease, or endocrine and osteoporotic disorders $[9,10]$. There are also reports on the role of vitamin D in regulating skeletal muscle tone, aerobic energy metabolism, and lipid metabolism [11]. There is also evidence that vitamin D may be an important regulator of the rate of energy metabolism [12-14].

\section{Objectives}

The aim of this study was to evaluate the resting metabolic rate in women with metabolic disorders. Moreover, the influence of diet, serum 25(OH)D concentration, nutritional status, and physical activity levels on the energy metabolism was also evaluated.

\section{Material and Method}

\subsection{Study and Control Group}

A total of 331 women took part in the case-control study. The study group consisted of 223 women, aged 19-81 years (the mean age $64.6 \pm 12.8$ years) with endocrine and/or osteoporotic disorders. The control group consisted of 108 women, aged 26-72 years (the mean age $61.4 \pm 11.3$ years), clinically healthy and without the above disorders.

In the study group, osteoporosis was found in 110 subjects (49.3\%), endocrine disorders (including hypothyroidism, Hashimoto's inflammation, inactive nodules) were found in 53 women $(23.8 \%)$, while 60 women $(26.9 \%)$ were affected by both these disorders. Patients with hypothyroidism and Hashimoto's disease were compensated with thyroid hormone replacement therapy.

In the study group, 26 women smoked cigarettes $(11.7 \%), 173$ subjects $(77.6 \%)$ had used vitamin D supplementation at a dose of 1000-2000 UI and calcium supplementation at a dose of 500-600 mg per day for at least three months. In the control group, 31 women (28.7\%) used vitamin D supplementation at a dose of 1000-2000 UI for at least three months. None of the women smoked.

The study was conducted according to the guidelines of the Declaration of Helsinki, and approved by the Bioethics Committee of the Medical University of $\operatorname{Lodz}$ (No. RNN/556/10/KB).

\subsection{Physical Activity}

In the all studied women, the level of physical activity was assessed using the International Physical Activity Questionnaire (IPAQ) [15]. The authors estimated the so called total physical activity expressed in MET_-min/week (Metabolic Equivalent of Work), where one MET represents resting energy expenditure assuming oxygen consumption of $3.5 \mathrm{~mL} / \mathrm{min} / \mathrm{kg}$ body weight.

There are three types of effort, namely light (walking), moderate (with slightly increased respiratory rate and slightly accelerated heart rate, such as carrying light objects, cycling at a normal speed, brisk walking), and intensive (with highly increased respiratory rate and accelerated heart rate, such as aerobics, fast cycling). The time spent on each type 
of activity in the last week is recorded and only efforts lasting at least 10 min are taken into account.

The questionnaire consists of 27 questions divided into 5 groups, each of which contains detailed questions on intensive, moderate, and walking activities undertaken by the subjects in the last week and related to their work, active mobility, housework, leisure, and sport. Moreover, time spent inactively during a week and the weekend is also analysed in the questionnaire.

The results were classified according to the following criteria:

1. Insufficient physical activity (less than $600 \mathrm{MET}-\mathrm{min} /$ week);

2. Sufficient physical activity (between 600 and $1500 \mathrm{MET}-\mathrm{min} /$ week);

3. Increased physical activity (1500-3000 MET_-min/week, but less than 3 days per week of intense exercise);

4. High physical activity (above $1500 \mathrm{MET}$-min/week but at least 3 days per week of intense exercise, or at least $3000 \mathrm{MET}$ - min/week).

The respondents completed the questionnaire with the help of a questioner. The questionnaire was thoroughly discussed prior to the commencement of the study, and particular attention was paid to explanation of the terminology used in the questionnaire and the interpretation of the intensity of physical efforts. For each category, the respondents separately identified the number of days and time spent on intensive and moderate activity as well as walking.

\subsection{Vitamin D}

Fasting blood for laboratory testing was collected from the ulnar vein. The obtained blood samples were used to determine the total $25(\mathrm{OH}) \mathrm{D}$ concentration level with an assay using the chemiluminescent immunoassay (CLIA) methodology. A serum 25(OH)D concentration of at least $30 \mathrm{ng} / \mathrm{mL}$ was considered normal, whereas the level below $30 \mathrm{ng} / \mathrm{mL}$ was considered insufficient (deficient concentration) [16].

\subsection{Metabolic Rate}

Indirect calorimetry was applied to assess the resting metabolic rate, using a Cosmed Fitmate Pro apparatus. A minimum 30-min measurement of absorbed oxygen and exhaled carbon dioxide was performed, and the amount of energy expended was calculated on the basis of the energy equivalent for oxygen.

All the studied women abstained from any strenuous physical activity for at least $24 \mathrm{~h}$ prior to the test. The measurement was made in the early morning, in a sitting position, in silence, without artificial light sources, and at room temperature.

Furthermore, using the Harris-Benedict formula, basal metabolism was calculated, then total metabolism, taking the subjects' level of physical activity into account [17].

\subsection{Anthropometry}

All the subjects had their waist measured, WHR was determined by dividing the waist circumference by hip circumference, and BMI (the body mass index) was determined by dividing body weight expressed in kilograms by height in square metres.

The body composition of the subjects was assessed with electrical bioimpedance analysis (BIA) using a Bodystat 1500 MDD apparatus. Fat body mass and fat-free body mass were measured.

\subsection{Nutrition Assessment}

Food intake was assessed with a 24-h questionnaire, collected three times from each subject (from two weekdays and one holiday). The average intake of energy and particular nutrients was assessed using the computer program Diet 5.0 (license number 52/PD/2013) [17]. 


\subsection{Statistical Analysis}

A statistical analysis was performed using the Statistica v.13 programme. Descriptive statistics with determination of the mean and standard deviation were made. The analysis of compatibility of the variable distribution with the normal distribution was performed with the application of the Shapiro-Wilk test. When the analysed variables appeared to be incompatible with the normal distribution, the authors used the Mann-Whitney test to compare the study and control groups. For ordinal variables or variables with distribution incompatible with the normal distribution and in order to determine the correlation between variables, the authors applied the Spearman's rank order correlation with determination of the Spearman's R coefficient and assessment of statistical significance. $p<0.05$ was considered significant.

\section{Results}

There were no statistical differences in age, weight, waist circumference, BMI, and WHR between the patients and controls, but subjects with metabolic disorders used vitamin $\mathrm{D}$ supplementation significantly more often than healthy women. With regards to the level of physical activity, the subjects in both the groups did not differ significantly. Every sixth respondent demonstrated insufficient physical activity. More than half of the respondents demonstrated a sufficient level. Every fifth respondent demonstrated an increased level of physical activity, whereas a high level of physical activity was noted in the smallest number of women. An analysis of body composition showed q significantly higher content of fat tissue and a lower level of fat-free mass in the group of women with metabolic disorders (Table 1).

The mean resting metabolic rate was significantly lower in the group of women with metabolic disorders than in the control group $(1332.7 \mathrm{kcal}$ vs. $1557.8 \mathrm{kcal}, \mathrm{Z}=4.4953$, $p=0.0000)$. However, it did not differ significantly between subjects with endocrine and osteoporotic disorders (1299.3 kcal vs. $1382.2 \mathrm{kcal}, \mathrm{Z}=0.7537, p=0.3582)$. Similar to the resting metabolic rate, the calculated value of basal metabolism was significantly higher in the control group. In contrast, there were no significant differences in the mean values of total metabolism between subjects with metabolic disorders and healthy subjects.

A correlation was found between serum $25(\mathrm{OH}) \mathrm{D}$ levels in healthy subjects and the resting metabolic rate $(\mathrm{R}=0.27, p=0.0000)$. This relationship was not confirmed in the group of women with metabolic disorders (Figure 1). Moreover, a significantly higher resting metabolic rate was found in women with normal serum 25(OH)D levels in comparison to subjects with deficient vitamin D levels (1538.5 kcal vs. $1284.9 \mathrm{kcal}$, $Z=3.7352, p<0.0001)$, regardless of any occurrence of endocrine and osteoporotic disorders (Table 2). Besides, women with a high resting metabolic rate appeared to demonstrate significantly higher $25(\mathrm{OH}) \mathrm{D}$ concentration than women with a low and moderate resting metabolic rate $(28.2 \pm 3.8 \mathrm{ng} / \mathrm{mL}$ vs. $20.5 \pm 3.1 \mathrm{ng} / \mathrm{mL}, \mathrm{Z}=5.0276, p<0.0001)$, regardless of any occurrence of metabolic disorders. The women with a high resting metabolic rate more often demonstrated sufficient $25(\mathrm{OH}) \mathrm{D}$ concentration than women with a low and moderate resting metabolic rate $(28.2 \pm 3.8$ vs. $20.5 \pm 3.1, Z=5.0276,<0.0001)$. They were characterised by a higher intake of proteins and fibre (Table 3 ).

The authors observed a correlation between the intake of selected nutrients and the resting metabolic rate. A positive correlation was found between the total dietary intake of vitamin $\mathrm{D}$ and the resting metabolic rate in healthy subjects $(R=0.25, p<0.0001)$. This observation was not confirmed in the patient group. In addition, all studied female subjects showed a positive correlation between resting metabolism and the total dietary intake of protein $(\mathrm{R}=0.22, p<0.0001)$, plant protein $(\mathrm{R}=0.23, p<0.0001)$, starch $(\mathrm{R}=0.24$, $p=0.0000)$, fibre $(R=0.21, p<0.0001)$, potassium $(R=0.21, p<0.0001)$, phosphorus $(\mathrm{R}=0.23, p<0.0001)$, and zinc $(\mathrm{R}=0.25, p<0.0001)$. There was also a relationship between the resting metabolic rate and the intake of vitamins, including thiamin $(\mathrm{R}=0.21, p<0.0001)$, riboflavin $(\mathrm{R}=0.21, p<0.0001)$, niacin $(\mathrm{R}=0.21, p<0.0001)$, pyridoxine $(\mathrm{R}=0.22, p<0.0001)$, and folic acid $(\mathrm{R}=0.26, p<0.0001)$. 
Physical activity level and body composition also affected the resting metabolic rate. A significantly higher resting metabolic rate was found in subjects with increased and high levels of physical activity compared to the other female subjects $(1631.6 \mathrm{kcal}$ vs. $1377.3 \mathrm{kcal}, \mathrm{Z}=6.8451, p<0.0001)$, regardless of an occurrence of metabolic disorders. In contrast, the control group demonstrated a relationship between body fat tissue $(R=-0.21, p<0.0001)$ and fat-free body mass $(R=0.32, p<0.0001)$ and the resting metabolic rate. The group of women with osteoporotic and endocrine disorders showed a similar relationship only for fat-free body mass $(\mathrm{R}=0.28, p<0.0001)$.

Table 1. Characteristics of the participating women.

\begin{tabular}{|c|c|c|c|}
\hline \multirow[t]{2}{*}{ Characteristics } & $\begin{array}{l}\text { Study Group } \\
\qquad n=223\end{array}$ & $\begin{array}{l}\text { Control Group } \\
\quad n=108\end{array}$ & $\begin{array}{c}\text { Z,p } \\
\text { Mann-Whitney Test }\end{array}$ \\
\hline & Mean $\pm \mathrm{SD} / n(\%)$ & Mean $\pm \mathrm{SD} / n(\%)$ & \\
\hline Age [years] & $64.6 \pm 12.8$ & $61.4 \pm 11.3$ & $4.2306,0.4673$ \\
\hline Body Mass Index (BMI) $\left[\mathrm{kg} / \mathrm{m}^{2}\right]$ & $27.8 \pm 5.5$ & $26.1 \pm 5.8$ & $1.1365,0.7671$ \\
\hline Waist Hip Ratio (WHR) & $0.8 \pm 0.1$ & $1.0 \pm 0.1$ & $1.4235,0.5328$ \\
\hline Waist circumference $[\mathrm{cm}]$ & $88.8 \pm 12.9$ & $87.2 \pm 7.2$ & $1.1463,0.5659$ \\
\hline Regular vitamin D supplements user $[n(\%)]$ & $173(77.6)$ & $31(28.7)$ & $4.5638,<0.0001$ \\
\hline \multicolumn{4}{|c|}{ Physical activity } \\
\hline Insufficient & $38(17.1)$ & $17(15.7)$ & $0.8735,0.5374$ \\
\hline Sufficient & $120(53.8)$ & $55(50.9)$ & $0.3467,0.3859$ \\
\hline Increased & $44(19.7)$ & $20(18.5)$ & $0.7436,0.4783$ \\
\hline High & $21(9.4)$ & $16(14.8)$ & $0.8834,0.7739$ \\
\hline \multicolumn{4}{|c|}{ Body composition } \\
\hline Body mass $[\mathrm{kg}]$ & $71.5 \pm 14.7$ & $73.5 \pm 7.9$ & $0.9453,0.6233$ \\
\hline Fat free mass $[\mathrm{kg}]$ & $46.1 \pm 6.2$ & $49.1 \pm 5.2$ & $2.9964,<0.0001$ \\
\hline Fat mass $[\mathrm{kg}]$ & $32.4 \pm 13.5$ & $28.4 \pm 8.3$ & $3.5762,<0.0001$ \\
\hline Fat mass $[\%]$ & $39.7 \pm 8.7$ & $36.2 \pm 4.7$ & $4.0276,<0.0001$ \\
\hline \multicolumn{4}{|c|}{ Metabolic Rate } \\
\hline Resting Metabolic Rate [kcal/d] & $1332.7 \pm 309.9$ & $1557.8 \pm 187.3$ & $7.0590,<0.0001$ \\
\hline Basal Metabolic Rate [kcal/d] & $1453.2 \pm 245.6$ & $1574.0 \pm 134.9$ & $5.0123,<0.0001$ \\
\hline Total Metabolic Rate [kcal/d] & $2409.7 \pm 254.7$ & $2427.5 \pm 288.7$ & $0.3632,0.0762$ \\
\hline Slow $[n(\%)]$ & $92(41.3)$ & $12(11.1)$ & $3.9432,<0.0001$ \\
\hline Normal $[n(\%)]$ & $83(37.2)$ & $14(13.0)$ & $2.9964,<0.0001$ \\
\hline $\operatorname{High}[n(\%)]$ & $48(21.5)$ & $82(75.9)$ & $4.0275,<0.0001$ \\
\hline \multicolumn{4}{|c|}{ Dietary intake } \\
\hline Energy [kcal/day] & $1415.7 \pm 447.4$ & $2127.2 \pm 1182.3$ & $4.2349,<0.0001$ \\
\hline Proteins [g/day] & $57.9 \pm 19.5$ & $99.6 \pm 45.8$ & $2.9836,<0.0001$ \\
\hline Proteins [\% total energy intake] & $16.7 \pm 4.5$ & $19.4 \pm 3.5$ & $2.7906,<0.0001$ \\
\hline Carbohydrates $[\mathrm{g} / \mathrm{day}]$ & $189.0 \pm 61.0$ & $268.8 \pm 139.8$ & $6.4326,<0.0001$ \\
\hline Carbohydrates [\% total energy intake] & $50.3 \pm 8.8$ & $48.1 \pm 8.8$ & $0.7683,0.7639$ \\
\hline Fats $[\mathrm{g} /$ day $]$ & $53.4 \pm 24.3$ & $79.3 \pm 57.7$ & $3.9465,<0.0001$ \\
\hline Fats [\% total energy intake] & $32.6 \pm 8.1$ & $32.1 \pm 7.2$ & $0.8032,0.4327$ \\
\hline MUFA [g/day] & $21.2 \pm 10.6$ & $30.8 \pm 28.9$ & $5.0348,<0.0001$ \\
\hline PUFA [g/day] & $8.1 \pm 4.2$ & $10.3 \pm 7.1$ & $3.9674,<0.0001$ \\
\hline SFA [g/day $]$ & $20.2 \pm 11.3$ & $34.4 \pm 28.4$ & $4.4876,<0.0001$ \\
\hline Fiber [g/day] & $15.7 \pm 5.9$ & $24.3 \pm 11.2$ & $4.0824,<0.0001$ \\
\hline $\begin{array}{c}\text { Vitamin D (without supplements) } \\
{[\mu \mathrm{g} / \text { day }]}\end{array}$ & $3.7 \pm 2.3$ & $7.4 \pm 5.6$ & $2.9987,<0.0001$ \\
\hline $\begin{array}{c}\text { Total vitamin D (including supplements) } \\
{[\mu \mathrm{g} / \text { day }]}\end{array}$ & $38.2 \pm 15.0$ & $21.1 \pm 13.6$ & $3.9075,0.0028$ \\
\hline \multicolumn{4}{|c|}{ Serum concentration } \\
\hline 25(OH)D Total [ng/mL] & $25.9 \pm 11.8$ & $28.1 \pm 9.1$ & $2.1808,0.0029$ \\
\hline $25(\mathrm{OH}) \mathrm{D}$ deficiency $[n(\%)]$ & $149(66.8)$ & $68(62.9)$ & $0.8725,0.8043$ \\
\hline
\end{tabular}




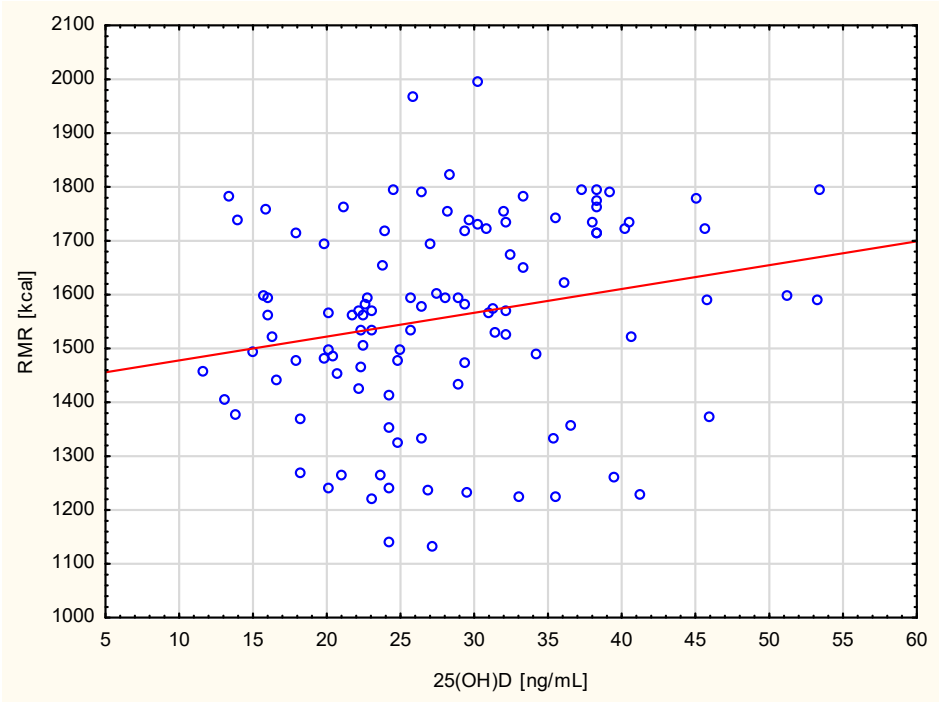

Figure 1. Correlation between $25(\mathrm{OH}) \mathrm{D}$ and $\mathrm{RMR}$ in healthy women.

Table 2. Characteristics of the participating women according to $25(\mathrm{OH}) \mathrm{D}$ concentration.

\begin{tabular}{|c|c|c|c|}
\hline \multirow[t]{2}{*}{ Characteristics } & $\begin{array}{c}25(\mathrm{OH}) \mathrm{D}<30 \mathrm{ng} / \mathrm{mL} \\
n=217\end{array}$ & $\begin{array}{c}25(\mathrm{OH}) \mathrm{D} \geq 30 \mathrm{ng} / \mathrm{mL} \\
n=114\end{array}$ & $\begin{array}{c}\mathrm{Z}, p \\
\text { Mann-Whitney Test }\end{array}$ \\
\hline & Mean $\pm \mathrm{SD} / n(\%)$ & Mean $\pm \mathrm{SD} / n(\%)$ & \\
\hline Age [years] & $65.2 \pm 10.2$ & $61.9 \pm 9.8$ & $3.2904,0.7325$ \\
\hline Body Mass Index (BMI) $\left[\mathrm{kg} / \mathrm{m}^{2}\right]$ & $26.9 \pm 4.9$ & $26.3 \pm 2.9$ & $1.1763,0.7781$ \\
\hline Waist Hip Ratio (WHR) & $0.8 \pm 0.3$ & $0.9 \pm 0.9$ & $1.6233,0.6371$ \\
\hline Waist circumference $[\mathrm{cm}]$ & $87.9 \pm 11.2$ & $86.2 \pm 6.9$ & $1.1393,0.4938$ \\
\hline Regular vitamin D supplements user $[n(\%)]$ & $94(43.3)$ & $110(96.5)$ & $2.5032,<0.0001$ \\
\hline \multicolumn{4}{|c|}{ Physical activity } \\
\hline Insufficient & $42(19.4)$ & $13(11.4)$ & $0.2756,0.6314$ \\
\hline Sufficient & $115(53.0)$ & $60(52.6)$ & $0.2961,0.7851$ \\
\hline Increased & $43(19.8)$ & $21(18.4)$ & $0.5826,0.4764$ \\
\hline High & $17(7.8)$ & $20(17.6)$ & $0.7463,0.3753$ \\
\hline \multicolumn{4}{|c|}{ Metabolic Rate } \\
\hline Resting Metabolic Rate $[\mathrm{kcal} / \mathrm{d}]$ & $1284.9 \pm 279.1$ & $1538.5 \pm 217.8$ & $3.7352, p<0.0001$ \\
\hline Basal Metabolic Rate $[\mathrm{kcal} / \mathrm{d}]$ & $1351.2 \pm 179.8$ & $1602.0 \pm 171.6$ & $1.7821,<0.0001$ \\
\hline Total Metabolic Rate $[\mathrm{kcal} / \mathrm{d}]$ & $25,024.2 \pm 174.8$ & $2479.5 \pm 308.1$ & $0.3037,0.1772$ \\
\hline Slow $[n(\%)]$ & $89(41.0)$ & $15(13.2)$ & $2.7472,<0.0001$ \\
\hline Normal $[n(\%)]$ & $86(39.6)$ & $11(9.6)$ & $1.9071,<0.0001$ \\
\hline $\operatorname{High}[n(\%)]$ & $42(19.4)$ & $88(77.2)$ & $3.1234,<0.0001$ \\
\hline \multicolumn{4}{|c|}{ Dietary intake } \\
\hline Energy [kcal/day] & $1493.7 \pm 507.8$ & $2221.8 \pm 982.4$ & $3.9843,<0.0001$ \\
\hline Proteins [g/day] & $55.8 \pm 15.9$ & $90.6 \pm 49.1$ & $1.9037,<0.0001$ \\
\hline Proteins [\% total energy intake] & $15.9 \pm 6.1$ & $20.7 \pm 3.1$ & $2.2972,<0.0001$ \\
\hline Carbohydrates $[\mathrm{g} /$ day $]$ & $177.9 \pm 60.5$ & $251.8 \pm 143.1$ & $3.7896,<0.0001$ \\
\hline Carbohydrates [\% total energy intake] & $53.3 \pm 6.8$ & $49.7 \pm 7.5$ & $0.7323,0.6739$ \\
\hline Fats $[\mathrm{g} /$ day $]$ & $57.4 \pm 21.5$ & $81.3 \pm 49.7$ & $1.0467,<0.0001$ \\
\hline Fats [\% total energy intake] & $30.7 \pm 9.1$ & $34.1 \pm 8.1$ & $0.2092,0.1357$ \\
\hline MUFA [g/day] & $20.9 \pm 9.9$ & $32.1 \pm 25.9$ & $4.1287,<0.0001$ \\
\hline PUFA [g/day] & $8.7 \pm 4.4$ & $12.1 \pm 5.7$ & $3.0631,<0.0001$ \\
\hline SFA [g/day] & $24.2 \pm 6.3$ & $37.4 \pm 19.7$ & $4.8671,<0.0001$ \\
\hline Fiber $[g /$ day $]$ & $13.9 \pm 6.2$ & $26.3 \pm 9.7$ & $3.8021,<0.0001$ \\
\hline Vitamin D (without supplements) [ $\mu \mathrm{g} /$ day] & $3.1 \pm 2.9$ & $8.2 \pm 4.8$ & $1.9042,<0.0001$ \\
\hline $\begin{array}{l}\text { Total vitamin D (including supplements) } \\
{[\mu \mathrm{g} / \text { day }]}\end{array}$ & $36.7 \pm 16.3$ & $20.3 \pm 14.1$ & $3.0472,0.0017$ \\
\hline
\end{tabular}


Table 3. Characteristics of the participating women according to the level of metabolic rate.

\begin{tabular}{|c|c|c|c|}
\hline \multirow[t]{2}{*}{ Characteristics } & $\begin{array}{c}\text { Slow and Normal } \\
\text { Metabolic Rate } \\
\quad n=201\end{array}$ & $\begin{array}{c}\text { High } \\
\text { Metabolic Rate } \\
n=130\end{array}$ & $\begin{array}{c}\mathrm{Z}, p \\
\text { Mann-Whitney Test }\end{array}$ \\
\hline & Mean $\pm \mathrm{SD} / n(\%)$ & Mean $\pm \mathrm{SD} / n(\%)$ & \\
\hline Age [years] & $67.4 \pm 11.1$ & $59.9 \pm 11.4$ & $1.2307,0.0025$ \\
\hline Body Mass Index (BMI) $\left[\mathrm{kg} / \mathrm{m}^{2}\right]$ & $28.3 \pm 6.2$ & $24.9 \pm 4.7$ & $1.1763,0.0018$ \\
\hline Waist Hip Ratio (WHR) & $1.1 \pm 0.9$ & $0.9 \pm 0.7$ & $1.0537,0.7872$ \\
\hline Waist circumference $[\mathrm{cm}]$ & $89.7 \pm 10.7$ & $85.2 \pm 7.4$ & $1.8378,0.6431$ \\
\hline Regular vitamin D supplements user $[n(\%)]$ & $92(45.8)$ & $112(86.2)$ & $2.5032,<0.0001$ \\
\hline \multicolumn{4}{|c|}{ Physical activity } \\
\hline Insufficient & $45(22.4)$ & $10(7.7)$ & $1.3432,0.0034$ \\
\hline Sufficient & $114(56.7)$ & $61(46.9)$ & $0.9468,0.0051$ \\
\hline Increased & $31(15.4)$ & $33(25.4)$ & $0.9456,0.0013$ \\
\hline High & $11(5.5)$ & $26(20.0)$ & $1.6874,0.0041$ \\
\hline \multicolumn{4}{|c|}{ Dietary intake } \\
\hline Energy [kcal/day] & $1523.7 \pm 587.1$ & $2171.8 \pm 782.7$ & $1.9563,<0.0001$ \\
\hline Proteins [g/day] & $56.8 \pm 15.8$ & $87.6 \pm 51.1$ & $1.9037,<0.0001$ \\
\hline Proteins [\% total energy intake] & $17.1 \pm 6.9$ & $22.4 \pm 3.7$ & $2.0962,<0.0001$ \\
\hline Carbohydrates $[\mathrm{g} /$ day $]$ & $197.9 \pm 56.5$ & $231.8 \pm 178.1$ & $2.7094,<0.0001$ \\
\hline Carbohydrates [\% total energy intake] & $54.1 \pm 7.2$ & $50.7 \pm 6.5$ & $0.9373,0.0023$ \\
\hline Fats $[\mathrm{g} /$ day $]$ & $58.8 \pm 23.4$ & $80.7 \pm 47.4$ & $1.9404,<0.0001$ \\
\hline Fats [\% total energy intake] & $32.5 \pm 8.7$ & $33.6 \pm 7.1$ & $0.4592,0.4953$ \\
\hline MUFA [g/day] & $19.3 \pm 7.8$ & $31.1 \pm 19.7$ & $3.3982,<0.0001$ \\
\hline PUFA [g/day] & $6.9 \pm 5.6$ & $14.1 \pm 3.5$ & $2.9934,<0.0001$ \\
\hline SFA $[g /$ day $]$ & $27.2 \pm 7.3$ & $35.4 \pm 18.9$ & $2.7073,<0.0001$ \\
\hline Fiber [g/day] & $11.9 \pm 4.2$ & $28.3 \pm 8.7$ & $4.2028,<0.0001$ \\
\hline Vitamin D (without supplements) [ $\mu \mathrm{g} /$ day] & $3.4 \pm 2.7$ & $8.9 \pm 5.1$ & $1.4541,<0.0001$ \\
\hline $\begin{array}{l}\text { Total vitamin D (including supplements) } \\
{[\mu \mathrm{g} / \text { day }]}\end{array}$ & $34.5 \pm 11.9$ & $26.3 \pm 11.8$ & $2.6734,0.0076$ \\
\hline \multicolumn{4}{|c|}{ Serum concentration } \\
\hline 25(OH)D Total [ng/mL] & $20.5 \pm 3.1$ & $28.2 \pm 3.8$ & $5.0276,<0.0001$ \\
\hline $25(\mathrm{OH}) \mathrm{D}$ deficiency $[n(\%)]$ & $151(75.1)$ & $66(50.8)$ & $1.2736,<0.0001$ \\
\hline
\end{tabular}

\section{Discussion}

Our study showed a positive relationship between vitamin D concentration and the resting metabolic rate in healthy subjects. This relationship was not confirmed in the group of women with metabolic disorders. Moreover, a significantly higher resting metabolic rate was found in women with normal serum $25(\mathrm{OH}) \mathrm{D}$ concentration compared to subjects with deficient serum 25(OH)D concentration, regardless of concomitance of osteoporotic and endocrine disorders. Our results therefore suggest an association between vitamin D nutritional status and the pace of energy metabolism. Studies conducted on mice showed that vitamin $\mathrm{D}$ is associated with regulation of energy metabolism rates $[18,19]$. In contrast, there are hardly any studies verifying the effect of vitamins on human energy expenditure and their results are often contradictory. A study by Marcotorchino et al. did not show a significant effect of vitamin D on energy metabolism. Nevertheless, it should be noted that this was a short-term observation [20]. Montenegro et al. included physically active adults in their study but they did not observe any effect of vitamin D supplementation on resting metabolism, the body composition and skeletal muscle function [11]. In other studies, this relationship was confirmed. Calton et al. demonstrated that serum vitamin $\mathrm{D}$ concentration is an independent predictor of the resting metabolic rate in Australian adults [21]. In this study, it was shown that an increase in $25(\mathrm{OH}) \mathrm{D}$ concentration from 40 to $75 \mathrm{nmol} / \mathrm{L}$ results in a change pertaining to daily resting metabolism by approximately $200 \mathrm{~kJ}$ per day, which simultaneously contributes to weight loss. The mechanism of the 
thermogenic action of vitamin D is not fully understood. There are hypotheses about its direct effect through $\mathrm{nVDR}$ or by influencing the skeletal muscle size and function, which results in an increased metabolic rate [18,22]. There is also speculation that vitamin D may affect the mitochondrial function and modulate resting oxygen consumption, which is positively correlated with the resting metabolic rate [23].

The influence of physical exercise on the resting metabolic rate is still a controversial and debated issue. In our study, patients with an increased and high level of physical activity were characterised by a significantly higher resting metabolic rate. A relationship between body composition and resting metabolism was also confirmed. Both in the group of healthy and diseased women, the content fat-free body mass positively correlated with the values of resting metabolism. Results of our study confirmed the observations of some authors but were contradictory to observations made by others. Some studies deny the influence of physical exercise on the resting metabolic rate [14,24]. Other studies confirmed this relationship, both in healthy subjects and those with metabolic disorders $[3,25,26]$. The body composition of the subjects is an important issue taken into account when assessing an influence of physical activity on the rate of energy metabolism. A study by Karstoft et al. showed that regardless of the type of undertaken physical activity, the body composition did not affect the changed resting metabolic rate. The rate was unchanged if the body composition was unchanged, too. Both fat and fat-free body mass affected the resting metabolic rate. However, when evaluating the effect of physical exercise on energy metabolism, only the changes in fat body mass, induced by physical exercise, determined changes in resting metabolism. A decrease in the volume of the fat body mass was accompanied by a decrease in the value of resting metabolism [7]. However, in our study, fat body mass was inversely related to resting metabolism, but only in the group of healthy women. Among women with metabolic disorders, only fat-free body mass correlated positively with values of the resting metabolic rate. Differences in the opinion on the possible influence of physical activity and nutritional status on the resting metabolic rate have not yet been clarified. Perhaps the type of programmed physical activity, its duration and intensity, as well as its influence on changes in body composition are important in assessing the potential impact on the body energy metabolism. In studies assessing the possible influence of physical activity on resting metabolism, changes in the body mass of the subjects were analysed, suggesting that they are a necessary condition to modify energy metabolism $[7,8]$.

The effect of selected nutrients on the rate of energy metabolism has been discussed for long. In our study, apart from vitamin D, we found a relationship between the resting metabolic rate and the total intake of protein, plant protein, starch, fibre, potassium, phosphorus, zinc, and B vitamins. The effect of a diet, especially of selected nutrients, on the body energy metabolism rate is mainly related to the so-called thermic effect of food, i.e., generation of heat after a meal (non-shivering thermogenesis). It can result in an increase in the total energy expenditure and a decrease in body weight. It depends, among other things, on the quality composition of the meal, its energy value, and the time of its consumption. In professional literature, proteins are most often mentioned as nutrients that influence human energy expenditure, although their influence on resting metabolism has not been clearly confirmed. However, a high protein intake is often associated with a decrease in body weight, which may explain this relationship [4,6]. On the other hand, carbohydrates and fats induce a significantly lower value of non-shivering thermogenesis than proteins [27-29]. However, studies showed a relationship between higher fibre intake and an enhanced thermic effect [4], which was also confirmed in the present study. In our study, the total intake of protein and plant protein also correlated with an increase in the resting metabolic rate. It is estimated that the intake of protein at the level of $11-30 \%$ of the total energy value of the diet increases the level of non-shivering thermogenesis up to $30 \%$, while a further increase in the protein intake (more than $30 \%$ of the energy value of the diet), does not cause a further thermal effect [30]. The source of protein is also significant, due to differences in metabolism of proteins of different origin. Differences in the rate and 
pace of changes in non-shivering thermogenesis after consumption of different types of proteins remain to be explained. A higher increase in non-shivering thermogenesis after the consumption of whey proteins than casein was shown, whereas differences between the effects of whey and soy proteins were not explained [29].

The present study has some limitations. It would be possible to obtain reliable data on the effect of undertaken physical activity on the resting metabolic rate if this rate were measured shortly after the activity. The authors did not determine how much the undertaken physical activity affected the body composition, which to some extent conditions the rate of energy metabolism and is also related to vitamin D nutritional status.

\section{Conclusions}

The $25(\mathrm{OH}) \mathrm{D}$ concentration, intake of selected nutrients, and body composition were factors influencing the resting metabolic rate in the group of healthy subjects assessed here. More research is needed to clarify the relationship between vitamin D status and metabolic rate in individuals with endocrine and osteoporotic disorders.

Author Contributions: Conceptualization, M.G. and E.S.; methodology, M.G. and E.G.; software, M.G. and M.K.; validation, M.G. and D.M.; formal analysis, M.G.; investigation, M.G.; resources, M.G.; data curation, M.G. and E.G.; writing—original draft preparation, M.G.; writing-review and editing, M.G.; visualization, M.G. and E.G.; supervision, M.G. and E.G.; project administration, M.G.; All authors have read and agreed to the published version of the manuscript.

Funding: This research received no external funding.

Institutional Review Board Statement: The study was conducted in accordance with the Declaration of Helsinki, and approved by the Bioethics Committee of the Medical University of Łodz (No. $\mathrm{RNN} / 556 / 10 / \mathrm{KB})$.

Informed Consent Statement: Informed consent was obtained from all subjects involved in the study.

Data Availability Statement: Publicly available datasets were not analyzed in this study.

Conflicts of Interest: The authors declare no conflict of interest.

\section{References}

1. McHill, A.; Wright, K., Jr. Role of sleep and circadian disruption on energy expenditure and in metabolic predisposition to human obesity and metabolic disease. Obes. Rev. 2017, 18, 15-24. [CrossRef] [PubMed]

2. Brinklov, C.F.; Thorsen, I.K.; Karstoft, K.; Brons, C.; Valentiner, L.; Langberg, H.; Vaag, A.A.; Nielsen, J.S.; Pedersen, B.K.; Ried-Larsen, M. Criterion validity and reliability of a smartphone delivered sub-maximal fitness test for people with type 2 diabetes. BMC Sports Sci. Med. Rehabil. 2016, 8, 31. [CrossRef] [PubMed]

3. Hirsch, K.R.; Smith-Ryan, A.E.; Blue, M.N.; Mock, M.G.; Trexler, E.T. Influence of segmental body composition and adiposity hormones on resting metabolic rate and substrate utilization in overweight and obese adults. J. Endocrinol. Investig. 2017, 40, 635-643. [CrossRef] [PubMed]

4. Calcagno, M.; Kahleova, H.; Alwarith, J.; Burgess, N.N.; Flores, R.A.; Busta, M.L.; Barnard, N.D. The thermic ffect of food: A Review. J. Am. Coll. Nutr. 2019, 38, 547-551. [CrossRef]

5. Bo, S.; Broglio, F.; Settanni, F.; Parasiliti Caprino, M.; Ianniello, A.; Mengozzi, G.; De Francesco, A.; Fadda, M.; Fedele, D.; Guggino, A.; et al. Effects of meal timing on changes in circulating epinephrine, norepinephrine, and acylated ghrelin concentrations: A pilot study. Nutr. Diabetes 2017, 7, 303. [CrossRef]

6. Soenen, S.; Martens, E.A.P.; Hochstenbach-Waelen, A.; Lemmens, S.G.T.; Westerterp-Plantenga, M.S. Normal protein intake is required for body weight loss and weight maintenance, and elevated protein intake for additional preservation of resting energy expenditure and fat free mass. J. Nutr. 2013, 143, 591-596. [CrossRef]

7. Karstoft, K.; Clark, M.A.; Jakobsen, I.; Muller, I.A.; Pedersen, B.K.; Solomon, T.P.; Ried-Larsen, M. The effects of 2 weeks of interval vs. continuous walking training on glycaemic control and whole-body oxidative stress in individuals with type 2 diabetes: A controlled, randomised, crossover trial. Diabetologia 2017, 60, 508-517. [CrossRef]

8. Karstoft, K.; Brinkløv, C.F.; Thorsen, I.K.; Nielsen, J.S.; Ried-Larsen, M. Resting metabolic rate does not change in response to different types of training in subjects with type 2 diabetes. Front. Endocrinol. 2017, 8, 132. [CrossRef]

9. Cashman, K.D.; Dowling, K.G.; Škrabáková, Z.; Gonzalez-Gross, M.; Valtueña, J.; De Henauw, S.; Moreno, L.; Damsgaard, C.T.; Michaelsen, K.F.; Mølgaard, C.; et al. Vitamin D deficiency in Europe-Pandemic? Am. J. Clin. Nutr. 2016, 103, $1033-1044$. [CrossRef] 
10. Płudowski, P.; Ducki, C.; Konstantynowicz, J.; Jaworski, M. Vitamin D status in Poland. Pol. Arch. Inter. Med. 2016, 126, 7-8. [CrossRef]

11. Montenegro, K.R.; Cruzat, V.; Melder, H.; Jacques, A.; Newsholme, P.; Ducker, K.J. Vitamin D supplementation does not impact resting metabolic rate, body composition and strength in vitamin D sufficient physically active adults. Nutrients 2020, $12,3111$. [CrossRef] [PubMed]

12. Calton, E.K.; Keane, K.; Soares, M.J. The potential regulatory role of vitamin D in the bioenergetics of inflammation. Curr. Opin. Clin. Nutr. Metab. Care 2015, 18, 367-373. [CrossRef] [PubMed]

13. Jastrzębska, M.; Kaczmarczyk, M.; Jastrzębski, Z. Effect of Vitamin D Supplementation on Training Adaptation in Well-Trained Soccer Players. J. Strength Cond. Res. 2016, 30, 2648-2655. [CrossRef] [PubMed]

14. Close, G.L.; Russell, J.; Cobley, J.; Owens, D.; Wilson, G.; Gregson, W.; Fraser, W.; Morton, J. Assessment of vitamin D concentration in non-supplemented professional athletes and healthy adults during the winter months in the UK: Implications for skeletal muscle function. J. Sports Sci. 2013, 31, 344-353. [CrossRef] [PubMed]

15. Stelmach, M. Physical activity assessment tools in monitoring physical activity: The Global Physical Activity Questionnaire (GPAQ), The International Physical Activity Questionnaire (IPAQ) or accelerometers-Choosing the best tools. Health Prob. Civiliz. 2018, 12, 57-63. [CrossRef]

16. Pludowski, P.; Holick, M.F.; Grant, W.B.; Konstantynowicz, J.; Mascarenhas, M.R.; Haq, A.; Povoroznyuk, V.; Balatska, N.; Barbosa, A.P.; Karonova, T.; et al. Vitamin D supplementation guidelines. J. Steroid Biochem. Mol. Biol. 2018, 175, 125-135. [CrossRef]

17. Jarosz, M. Standards of Human Nutrition, 3rd ed.; National Food and Nutrition Institute: Warsaw, Poland, 2012 ; pp. 154-179.

18. Bouillon, R.; Carmeliet, G.; Lieben, L.; Watanabe, M.; Perino, A.; Auwerx, J.; Schoonjans, K.; Verstuyf, A. Vitamin D and energy homeostasis-of mice and men. Nat. Rev. Endocrinol. 2014, 10, 79-87. [CrossRef]

19. Wong, K.E.; Kong, J.; Zhang, W.; Szeto, F.L.; Ye, H.; Deb, D.K.; Brady, M.J.; Li, J.C. Targeted expression of human vitamin D receptor in adipocytes decreases energy expenditure and induces obesity in mice. J. Biol. Chem. 2011, 286, 33804-33810. [CrossRef]

20. Marcotorchino, J.; Tourniaire, F.; Astier, J.; Karkeni, E.; Canault, M.; Amiot, M.J.; Bendahan, D.; Bernard, M.; Martin, J.C.; Giannesini, B.; et al. Vitamin D protects against diet-induced obesity by enhancing fatty acid oxidation. J. Nutr. Biochem. 2014, 25, 1077-1083. [CrossRef]

21. Calton, E.K.; Pathak, K.; Soares, M.J.; Alfonso, H.; Keane, K.N.; Newsholme, P.; Cummings, N.K.; Chan, W.; Ping-Delfos, S.; Hamidi, A. Vitamin D status and insulin sensitivity are novel predictors of resting metabolic rate: A cross-sectional analysis in Australian adults. Eur. J. Nutr. 2016, 55, 2075-2080. [CrossRef]

22. Beaudart, C.; Buckinx, F.; Rabenda, V.; Gillain, S.; Cavalier, E.; Slomian, J.; Petermans, J.; Reginster, J.Y.; Bruyere, O. The effects of vitamin D on skeletal muscle strength, muscle mass, and muscle power: A systematic review and meta-analysis of randomized controlled trials. J. Clin. Endocrinol. Metab. 2014, 99, 4336-4345. [CrossRef] [PubMed]

23. Sinha, A.; Hollingsworth, K.G.; Ball, S.; Cheetham, T. Improving the vitamin D status of vitamin D deficient adults is associated with improved mitochondrial oxidative function in skeletal muscle. J. Clin. Endocrinol. Metab. 2013, 98, E509-E513. [CrossRef] [PubMed]

24. Drincic, A.T.; Armas, L.A.; Van Diest, E.E.; Heaney, R.P. Volumetric dilution, rather than sequestration best explains the low vitamin D status of obesity. Obesity 2012, 20, 1444-1448. [CrossRef]

25. Muller, M.J.; Enderle, J.; Bosy-Westphal, A. Changes in energy expenditure with weight gain and weight loss in humans. Curr. Obes. Rep. 2016, 5, 413-423. [CrossRef] [PubMed]

26. Müller, M.J.; Enderle, J.; Pourhassan, M.; Braun, W.; Eggeling, B.; Lagerpusch, M.; Glüer, C.-C.; Kehayias, J.J.; Kiosz, D.; Bosy-Westphal, A. Metabolic adaptation to caloric restriction and subsequent refeeding: The Minnesota Starvation Experiment revisited. Am. J. Clin. Nutr. 2015, 102, 807-819. [CrossRef]

27. Bo, S.; Fadda, M.; Castiglione, A.; Ciccone, G.; De Francesco, A.; Fedele, D.; Guggino, A.; Parasiliti Caprino, M.; Ferrara, S.; Vezio Boggio, M.; et al. Is the timing of caloric intake associated with variation in diet-induced thermogenesis and in the metabolic pattern? A randomized cross-over study. Int. J. Obes. 2015, 39, 1689-1695. [CrossRef]

28. Kassis, A.; Godin, J.P.; Moille, S.E.; Nielsen-Moennoz, C.; Groulx, K.; Oguey-Araymon, S.; Praplan, F.; Beaumont, M.; Sauser, J.; Monnard, I.; et al. Effects of protein quantity and type on diet induced thermogenesis in overweight adults: A randomized controlled trial. Clin. Nutr. 2019, 38, 1570-1580. [CrossRef]

29. Ebbeling, C.B.; Feldman, H.A.; Klein, G.L.; Wong, J.M.W.; Bielak, L.; Steltz, S.K.; Luoto, P.K.; Wolfe, R.R.; Wong, W.W.; Ludwig, D.S Effects of a low carbohydrate diet on energy expenditure during weight loss maintenance: Randomized trial. BMJ 2018, $363, \mathrm{k} 4583$. [CrossRef]

30. Ravn, A.M.; Gregersen, N.T.; Christensen, R.; Rasmussen, L.G.; Hels, O.; Belza, A.; Raben, A.; Larsen, T.M.; Toubro, S.; Astrup, A. Thermic effect of a meal and appetite in adults: An individual participant data meta-analysis of meal-test trials. Food Nutr. Res. 2013, 57, 19676. [CrossRef] 